\title{
Beta-D-fructofuranosidase production by Aspergillus niger IBGE 01 using shaken flask technique of submerged fermentation
}

Kashif Ahmed ${ }^{1 *}$, Seharish Munawar ${ }^{2}$ and Muhammad Ansar Khan ${ }^{3}$

1. Department of Chemistry, N.E.D. University of Engineering \& Technology, Karachi, Pakistan

2. Directorate of Fisheries Sindh, Research and Development, Karachi, Pakistan

3. Department of Chemical Engineering, N.E.D. University of Engineering and Technology, Karachi, Pakistan.

*Corresponding author's email: kashif25473@yahoo.com

Citation

Kashif Ahmed, Seharish Munawar and Muhammad Ansar Khan. Beta-D-Fructofuranosidase production by Aspergillus niger IBGE 01 using shaken flask technique of submerged fermentation. Pure and Applied Biology. Vol. 4, Issue 3, 2015, pp 323-330. http://dx.doi.org/10.19045/bspab.2015.43008

\begin{tabular}{lll}
\hline \hline Received: $25 / 04 / 2015$ & Revised: 02/07/2015 & Accepted: 10/07/2015 \\
\hline \hline
\end{tabular}

\section{Abstract}

The modern biotechnological set up has motivated the need of enlarged survey of microorganisms which could be utilised in the extreme conditions of industries. In this work optimization parameters in submerged fermentation were studied for the production of Invertase from Aspergillus niger IBGE 01 using agricultural wastes (sunflower waste, cotton stalk and rice husk) as well as agro industrial wastes(date syrup and molasses) as sources of carbon. Effects of incubation time period (24-240 h), various cultural media (CM1, CM2, CM3, CM4 and CM5) sources of nitrogen (Corn steep, Casein, Potassium Nitrate Albumin Ammonium Sulphate Urea and Yeast Extract), $\mathrm{pH}$ (4.0-9.0), temperatures $\left(30-70^{\circ} \mathrm{C}\right)$, inoculum size $\left(4 \times 10^{6}-8 \times 10^{6}\right.$ conidia/mL) and agitation rate (50-300 rev/min) were also investigated for maximum invertase production. Optimal conditions for the production of invertase $(8.23 \mathrm{U} / \mathrm{mL})$ by Aspergillus niger IBGE 01 were observed when the strain was grown on culture medium CM1 containing yeast extract as a source of nitrogen, molasses as a source of carbon after $72 \mathrm{~h}$ of incubation at $40^{\circ} \mathrm{C}$, initial $\mathrm{pH} 6.0$, inoculum size of $5 \times 10^{6}$ conidia in $50 \mathrm{~mL}$ of culture medium and agitation rate of $150 \mathrm{rev} / \mathrm{min}$. The strain was proved $\mathrm{pH}$ (up to 9) and thermo stable (up to $60^{\circ} \mathrm{C}$ ) therefore can be used in industries for invertase production.

Key words: Invertase; Aspergillus niger; Optimization.

Introduction

The modern biotechnological setup due to increasing demand of enzymes has motivated the need for enlarged survey of microorganisms surviving and producing enzyme in extreme conditions [1]. For the production of large quantities of enzymes filamentous fungi have biotechnological importance [2].

Invertase (Enzyme Code 3.2.1.26), splits sucrose into glucose and fructose. It is one of the most widely used enzymes by food industry in making chocolate covered cherries. This enzyme is also used in paper industry and to make artificial honey in which it contributes to anti-bacterial 
properties $[2,3]$.

In the present work specific interest has been focused on agriculture waste like sunflower cotton stalk rice husk date syrup and molasses because they are usually related with pollution. Being the cost effective sources of carbon agricultural wastes have a potential for conversion into useful products [1]. In this work the secretion of invertase by Aspergillus niger IBGE 01 in submerged fermentation with all optimised parameters are being reported because no work is done to optimize all parameters for the production of invertase from this strain.

\section{Materials and Methods}

Aspergillus niger IBGE 01 was obtained from the Institute of Biotechnology \& Genetic Engineering University of Sindh and the culture was maintained as followed by Dahot [4].

\section{Optimization of parameters}

All experiments were done in such a way that the parameter optimized in one experiment was fixed in the following experiments.

\section{Culture medium}

First of all the most suitable culture medium was determined. Composition of various culture media were (in $\mathrm{g} / \mathrm{L}$ )

CM1: Dextrose 10, Peptone 5, Epsom salt 5, $\mathrm{KH}_{2} \mathrm{PO}_{4} 5$, Common salt 2.5 and ferrous sulphate hepta hydrate 0.01 [5].

CM2: Yeast extract 10, peptone 20 and sucrose 20 [6].

CM3: Yeast extract 20, peptone 40, sucrose 20, $\mathrm{KH}_{2} \mathrm{PO} 42$ and Epsom salt 1 [7].

CM4: $\mathrm{NaNO}_{3} 3, \mathrm{KCl}$ 0.5, Epsom salt 0.5, ferrous sulphate hepta hydrate $0.01, \mathrm{~K}_{2} \mathrm{HPO}_{4}$ 1, Sucrose 30 [8].

CM5: Sucrose 40, Corn steep liquor 30, $\mathrm{NaNO}_{3} 3, \mathrm{KH}_{2} \mathrm{PO}_{4}$ 0.5, Epsom salt 0.05, $\mathrm{CaCO}_{3} 2.5$ [9].

\section{Incubation time}

After the determination of the most suitable culture medium, optimum incubation time period was determined. It was done by growing the strain on CM1 at various interval of time from 24-240 hours.

\section{Carbon sources}

After the optimization of incubation time the most suitable carbon source was determined. It was done by replacing the glucose (control) of CM1 by various wastes including sunflower waste, cotton stalk, rice husk which were hydrolysed by $0.3 \mathrm{~N} \mathrm{H}_{2} \mathrm{SO}_{4}$ and $0.6 \mathrm{~N}$ $\mathrm{H}_{2} \mathrm{SO}_{4}$. Date syrup and molasses were used $0.5 \%$ and $1 \%$ in place of glucose (control).

\section{Nitrogen sources}

After the determination of the most suitable carbon source various nitrogen sources were checked for optimum production of invertase. It was done by replacing peptone of CM1 by Corn steep, Casein, Potassium Nitrate Albumin Ammonium Sulphate Urea and Yeast Extract.

\section{Incubation temperature}

The most suitable culture medium CM1 was tested on varying temperature from $30-70^{\circ} \mathrm{C}$ to determine the most suitable incubation temperature.

\section{Initial $\mathrm{pH}$ of medium}

The initial $\mathrm{pH}$ of a medium has an effect on growth and productivity of microorganism. A range of $\mathrm{pH}$ between 4.0-9.0 was checked for optimum production.

\section{Inoculum size}

Productivity was also checked in terms of No. of conidia/mL in $50 \mathrm{~mL}$ of optimised culture medium in order to obtain the optimized inoculum size of culture medium. The No. of conidia $/ \mathrm{mL}$ was counted by haemocytometer.

Agitation rate

Effect of Agitation rate was also checked for optimization at 50,100,150,200, 250 and 300 $\mathrm{rev}$. /minute in orbital shaking incubator.

\section{Determination of enzyme activity}

Invertase activity was determined by BernFeld method [10]. One unit of invertase activity is the amount of enzyme which releases $1 \mu \mathrm{g}$ of reducing sugar at $37^{\circ} \mathrm{C}$ per minute. 


\section{Results and Discussion \\ Effect of culture media}

Effects of various culture media on invertase production by $A$. niger IBGE 01 after $24 \mathrm{~h}$, at $30^{\circ} \mathrm{C}$, initial $\mathrm{pH} 6.0$, inoculum size $4 \times 10^{6}$ conidia and agitation rate $50 \mathrm{rev} / \mathrm{min}$ are poltted (Fig.1). The strain was grown on five different culture media i.e. CM1, CM2, CM3, CM4 and CM5. It was capable of growing well on all types of culture media but production of invertase was maximum (1.87 U/mL) on culture medium CM1 containing $(\mathrm{g} / \mathrm{L})$ dextrose 10 , peptone 5, epsom salt 5, $\mathrm{KH}_{2} \mathrm{PO}_{4} 5$, common salt 2.5, ferrous sulphate hepta hydrate 0.01 , $\mathrm{ZnSO}_{4} .7 \mathrm{H}_{2} \mathrm{O}$ 0.002, $\mathrm{MnSO}_{4} . \mathrm{H}_{2} \mathrm{O} 0.001$ and thiamine hydrochloride 0.001. CM1 was selected for the next study of invertase production.

Selection of the most suitable culture media has the deep effect on enzyme production. Many researchers all over the world have reported different culture media for maximum invertase production $[6-9,18]$.

\section{Effect of incubation time period}

Effects of incubation time periods on invertase production by $A$. niger IBGE 01 in $\mathrm{CM} 1$ at $30^{\circ} \mathrm{C}$, initial $\mathrm{pH} 6.0$, inoculum size $4 \times 10^{6}$ conidia and agitation rate $50 \mathrm{rev} / \mathrm{min}$ are poltted (Fig. 2). Invertase activity was measured at regular interval of $24 \mathrm{~h}$ and it was found that the maximum activity (2.34 $\mathrm{U} / \mathrm{mL}$ ) was observed after $72 \mathrm{~h}$ of incubation. On prolonged incubation enzyme activity was decreased, which may be due to denaturing of enzyme or synthesis of inhibiting metabolite [1]. Incubation time period of $72 \mathrm{~h}$ was reported for invertase production by Alternaria tenuis and Saccharomyces crevisiae [9] while 96 h by Aspergillus ochraceus [11].

\section{Effect of carbon sources}

Effects of various carbon sources on invertase production by $A$. niger IBGE 01 after $72 \mathrm{~h}$ in $\mathrm{CM} 1$ at temperature $30^{\circ} \mathrm{C}$, initial $\mathrm{pH} 6.0$, inoculum size $4 \times 10^{6}$ conidia and agitation rate $50 \mathrm{rev} / \mathrm{min}$ are shown in Fig. 3. In the present work date syrup, molasses, sunflower waste, cotton stalk and rice husk have been used as sources of carbon, which were (except date syrup and molasses) hydrolyzed by $0.3 \mathrm{~N}$ and $0.6 \mathrm{~N}$ of $\mathrm{H}_{2} \mathrm{SO}_{4}$. It was observed that invertase activities were lower than control $(2.34 \mathrm{U} / \mathrm{mL})$ in case of $0.3 \mathrm{~N}$ sulphuric acid hydrolysed agriculture waste $(0.85,1.12$ and $1.48 \mathrm{U} / \mathrm{mL}$ for cotton stalk, sunflower waste and rice husk respectively) and higher with $0.5 \%$ of date syrup and molasses (2.58 and $3.06 \mathrm{U} / \mathrm{mL}$ respectively). Invertase activities were closer to control, glucose $(2.34 \mathrm{U} / \mathrm{mL})$ when $0.6 \mathrm{~N}$ sulphuric acid hydrolysed agriculture waste $(1.86,1.82$ and $2.09 \mathrm{U} / \mathrm{mL}$ for cotton stalk, sunflower waste and rice husk respectively) and enzyme activities were higher when $1 \%$ of date syrup (2.57 U/mL) and molasses (3.78 $\mathrm{U} / \mathrm{mL}$ ) were used. A number of nonconventional carbon sources such as starch, oilcakes, cassava starch, potato, corn and tapioca have been also used in submerged fermentation for various enzymes production [12-15, 20, 22].

\section{Effect of nitrogen sources}

Effects of various nitrogen sources on invertase production by Aspergillus niger IBGE 01 after $72 \mathrm{~h}$ in CM1 containing molasses as carbon source at $30^{\circ} \mathrm{C}$, initial $\mathrm{pH}$ 6.0, inoculum size $4 \times 10^{6}$ conidia and agitation rate $50 \mathrm{rev} / \mathrm{min}$ are poltted (Fig. 4). Various nitrogen sources (casein, corn steep liquor, potassium nitrate, albumin, ammonium sulphate, urea and yeast extract) were used in the quantity of 0.25 and $0.50 \%$ in place of peptone (control having enzyme activity $3.91 \mathrm{U} / \mathrm{mL}$ ). The strain showed the capability of utilizing well all types (except urea) of nitrogen sources but yeast extract was found to be the best $(3.81 \mathrm{U} / \mathrm{mL}$ in 0.25 $\%$ and $4.58 \mathrm{U} / \mathrm{mL}$ in $0.50 \%$ ). Increase in enzyme activity may be due to the reason that various other enzymes are also produced, which may affect at the 
production of each other [16]. Yeast extract was also reported as the best nitrogen source for Candida utilis, Saccharomyces cerevisiae [6] and Aspergillus ochraceus [11]. Very low values $(0.26 \mathrm{U} / \mathrm{mL}$ in $0.25 \%$ and $0.09 \mathrm{U} / \mathrm{mL}$ in $0.5 \%$ ) of invertase activities were observed when urea was used as nitrogen source. It may be due to denaturing effect of urea on invertase [17].

\section{Effect of temperature}

The effects of incubation temperatures on invertase production by Aspergillus niger IBGE 01 after $72 \mathrm{~h}$ in CM1 containing molasses as carbon source, yeast extract nitrogen source, at initial $\mathrm{pH} 6.0$, inoculum size $4 \times 10^{6}$ conidia and agitation rate 50 rev/min are presented (Fig. 5). The fermentation medium was incubated at a range of temperatures $20-70^{\circ} \mathrm{C}$. Invertase activity was the highest $(5.67 \mathrm{U} / \mathrm{mL})$ at $40^{\circ}$ C. Similar optimum temperature has been reported for P. lilacinum [2].

\section{Effect of initial pH}

The effects of initial $\mathrm{pH}$ of fermentation medium on invertase production by $A$. niger IBGE 01 after $72 \mathrm{~h}$ in CM1 containing molasses as carbon source, yeast extract nitrogen source, temperature $40^{\circ} \mathrm{C}$, inoculum size $4 \times 10^{6}$ conidia and agitation rate $50 \mathrm{rev} / \mathrm{min}$ are shown (Fig. 6). A range of $\mathrm{pH}$ (4.0 to 9.0) was studied and found that initial $\mathrm{pH}$ of 6.0 would be the best for maximum enzyme production $(5.67 \mathrm{U} / \mathrm{mL})$. Similar initial pH 6.0 was also reported by Dworschack \& Wickerham [6] for invertase production from Saccharomyces cerevisiae. Results also indicate that invertase production is appreciable between $\mathrm{pH} 5-8$, which shows its $\mathrm{pH}$ stability that is a requirement for industrial use of a microorganism [1].

\section{Effect of inoculum size}

Effects of inoculum sizes on invertase production by $A$. niger IBGE 01 after $72 \mathrm{~h}$ in CM1 containing molasses as carbon source, yeast extract nitrogen source, temperature $40^{\circ}$ $\mathrm{C}$, at initial $\mathrm{pH} 6.0$ and agitation rate 50 rev/min are presented (Fig. 7). The quantity of enzyme produced by a fungus depends upon number of conidia added to the culture medium. Flasks were added with $4 \times 10^{6}-8 \times 10^{6}$ conidia and maximum invertase activity $(7.01 \mathrm{U} / \mathrm{mL})$ was observed when $5 \times 10^{6}$ conidia were added to the medium. Literature survey revealed that researchers have used inoculum sizes on the basis of percentage of fermentation media $[1,4,11]$ but in the present study counted conidia were added to the medium in order to generate more accurate results. Large inoculum size causes overgrowth and nutritional imbalanced resulting less production of enzyme $[1,4,11,21]$.

\section{Effect of agitation rate}

The effects of agitation rates on invertase production by $A$. niger IBGE 01 after $72 \mathrm{~h}$ in $\mathrm{CM} 1$ containing molasses as carbon source, yeast extract nitrogen source, $40^{\circ} \mathrm{C}$, at initial $\mathrm{pH} 6.0$ and inoculum size $5 \times 10^{6}$ conidia are exhibited (Fig. 8). Agitation rate is another factor which affects the enzyme production. Agitation of media ensures the homogeneous supply of nutrients [27]. The fermentation medium was agitated at 50, 100, 150, 200, 250 and $300 \mathrm{rev} / \mathrm{min}$. Invertase activity was maximum $(8.23 \mathrm{U} / \mathrm{mL})$ at $150 \mathrm{rev} / \mathrm{min}$. Literature survey revealed that researchers reported various agitation rates (100-200 $\mathrm{rev} / \mathrm{min}$ ) for enzymes production by different microorganisms $[4,19,23-26]$. 


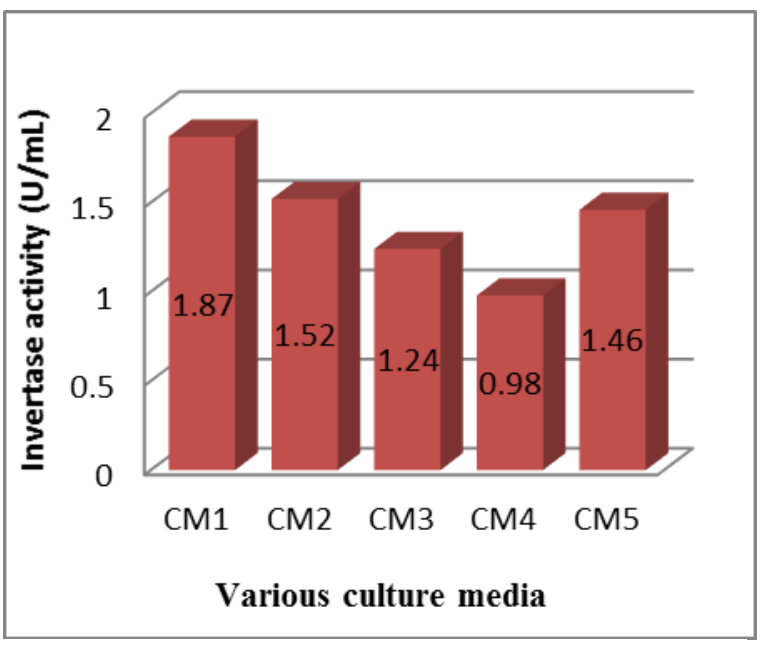

Fig.1. Effects of various culture media on invertase production by Aspergillus niger after $24 \mathrm{~h}$, at $30^{\circ} \mathrm{C}$, initial $\mathrm{pH}$ 6.0, inoculum size $4 \times 10^{6}$ conidia and agitation rate $50 \mathrm{rev} / \mathrm{min}$.

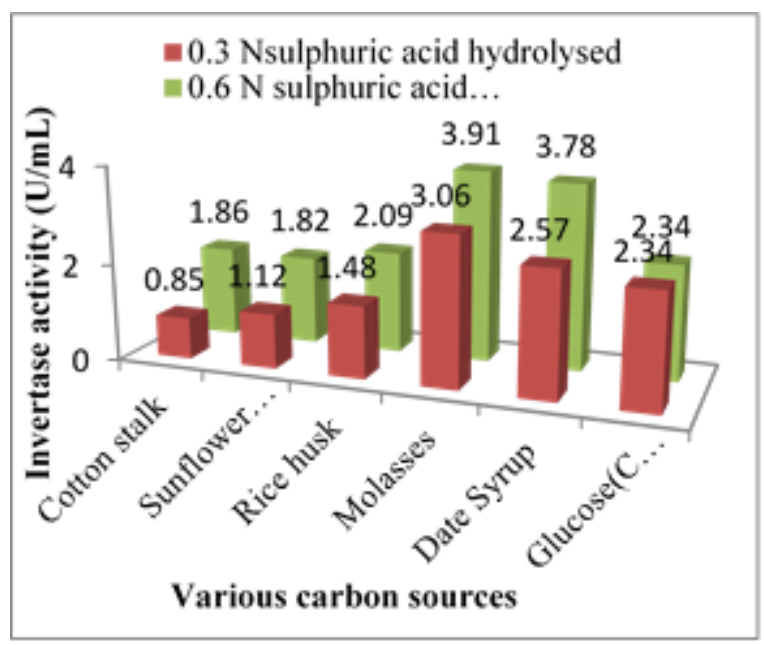

Fig. 3. Effects of various carbon sources on invertase production by $A$. niger after $72 \mathrm{hinCM}$ at $30^{\circ} \mathrm{C}$, initial $\mathrm{pH} 6.0$, inoculum size $4 \times 10^{6}$ coni dia and agitationr ate 50 $\mathrm{rev} / \mathrm{min}$.

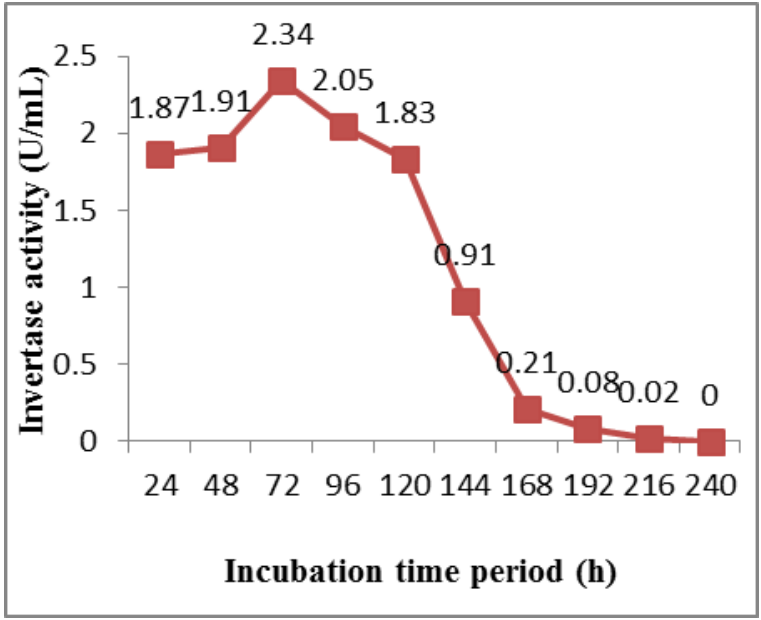

Fig. 2. Effects of incubation time periods on invertase production by $A$. niger in $\mathrm{CM} 1$ at $30^{\circ} \mathrm{C}$, initial $\mathrm{pH}$ 6.0 , inoculum size $4 \times 10^{6}$ conidia and agitation rate 50 $\mathrm{rev} / \mathrm{min}$

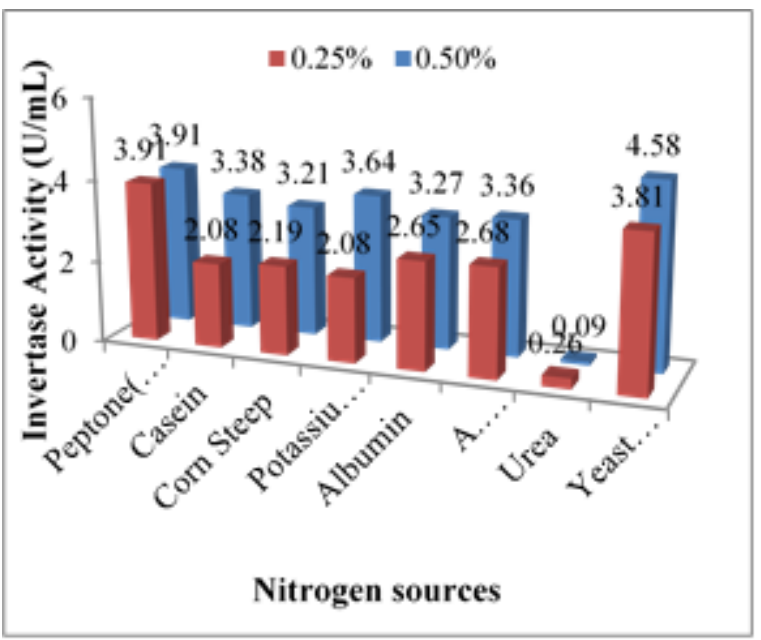

Fig. 4. Effects of incubation temperatures on invertase production by $A$. niger after $72 \mathrm{~h}$ in CM1 containing molasses as carbon source, yeast extract nitrogen source, at initial $\mathrm{pH} 6.0$, inoculum size $4 \times 10^{6}$ conidia and agitation rate $50 \mathrm{rev} / \mathrm{min}$ 


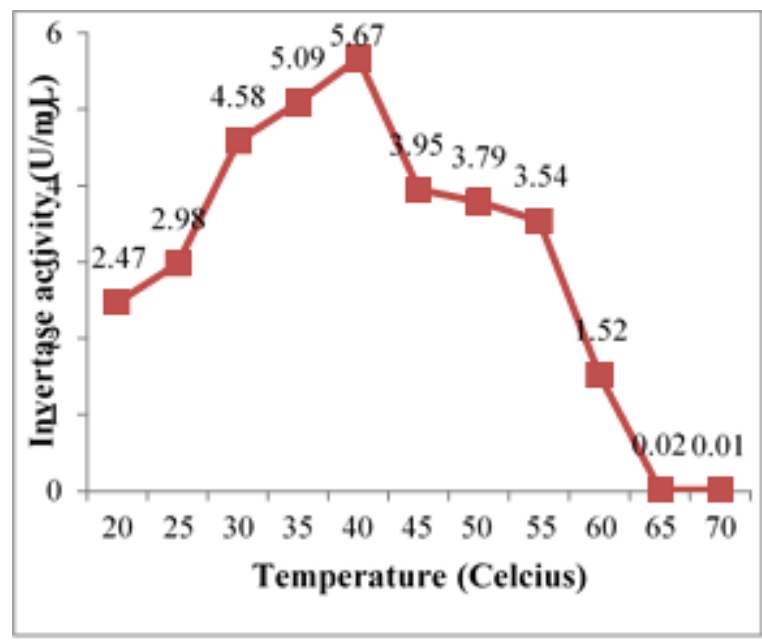

Fig. 5. Effects of incubation temperatures on invertase production by $A$. niger after $72 \mathrm{~h}$ in CM1 containing molasses as carbon source, yeast extract nitrogen source, at initial pH 6.0, inoculum size $4 \times 10^{6}$ coni dia and agitation rate $50 \mathrm{rev} / \mathrm{min}$

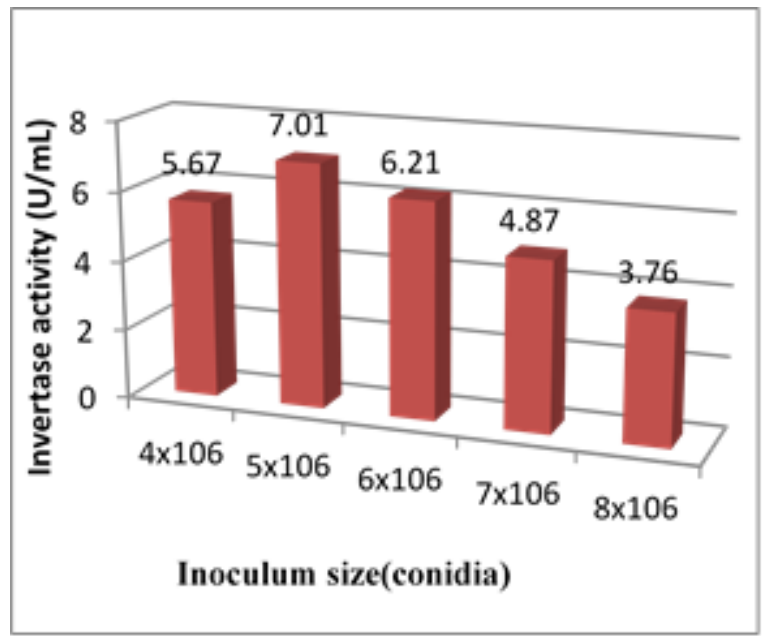

Fig. 7. Effects of inoculum sizes on invertase production by $A$. niger after $72 \mathrm{~h}$ in CM1 containing molasses as carbon source, yeast extract nitrogen source, at $40^{\circ} \mathrm{C}$, initial $\mathrm{pH} 6.0$ and agitation rate 50 $\mathrm{rev} / \mathrm{min}$.

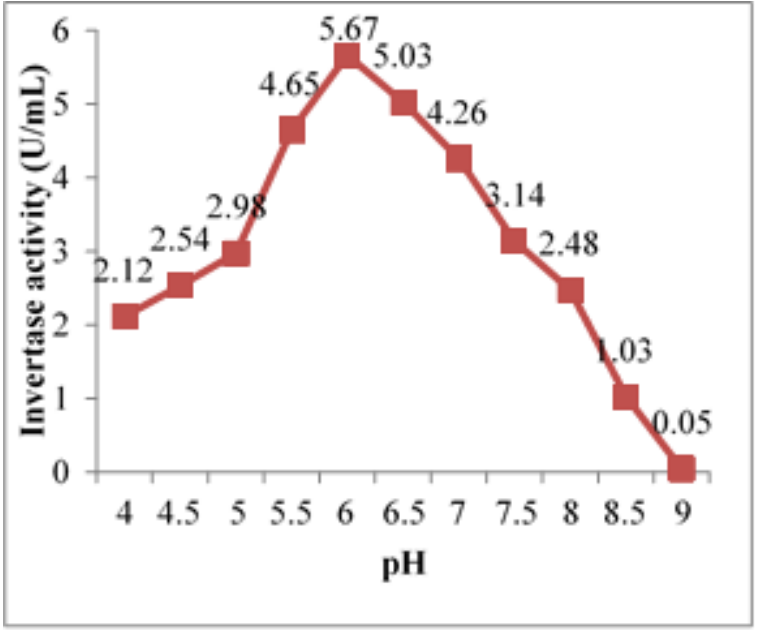

Fig. 6. Effects of initial $\mathrm{pH}$ of fermentation m edium on invertase production by $A$. niger after $72 \mathrm{~h}$ in CM1 containing molasses as carbon source, yeast extract nitrogen source, temperature $40^{\circ} \mathrm{C}$, inoculum size $4 \times 10^{\circ}$ conidia and agitation rate $50 \mathrm{rev} / \mathrm{m}$ in.

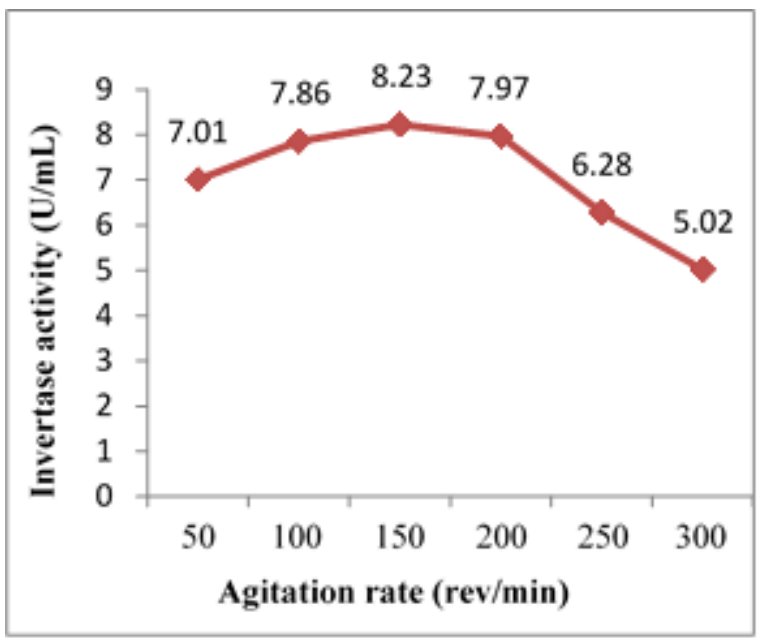

Fig. 1. Effects of agitation rates on invertase production by $A$. niger after $72 \mathrm{~h}$ in CM1 containing molasses as carbon source, yeast extract nitrogen source, at $40^{\circ} \mathrm{C}$, initial $\mathrm{pH} 6.0$ and inoculum size $5 \times 10^{6}$ coni dia. 


\section{Conclusion}

In the present study local fungus Aspergillus niger IBGE 01 was used and optimization parameters were determined for maximum invertase production by using various agricultural/industrial wastes as sources of carbon. Optimal conditions for the production of invertase $(8.23 \mathrm{U} / \mathrm{mL})$ by Aspergillus niger IBGE 01 were observed when the strain was grown on culture medium CM1 containing yeast extract as a source of nitrogen, molasses as a source of carbon after $72 \mathrm{~h}$ of incubation at $40^{\circ} \mathrm{C}$, initial $\mathrm{pH} 6.0$, inoculum size of $5 \times 10^{6}$ conidia in $50 \mathrm{~mL}$ of culture medium and agitation rate of $150 \mathrm{rev} / \mathrm{min}$. The strain was proved $\mathrm{pH}$ (up to 9) and thermo stable (up to $60^{\circ} \mathrm{C}$ ) therefore can be used in industries for invertase production.

\section{References}

1. Mamma D, Kourtoglou E \& Christakopoulos P (2008). Fungal Multienzyme Production on Industrial By products of The Citrus-Processing Industry. Bioresour Technol 99: 2373-2383.

2. Ahmed K, Dahot MU, Haq Q \& Valeem EE (2011). Optimal Conditions of the Production of Commercial Enzyme by Penicillium Lilacinum by Culturing on Agroindustrial Waste. Int J Biol Biotechnol 8(2):213-219.

3. Kulshrestha S (2013). Invertase and its applications- a brief review. J Pharm Res 7(1): 792-797.

4. Dahot MU (1986). Biosynthesis of Invertase by Penicillium expansum. J Pure App Sci 5(1): 23-26.

5. Burrel RG, Clayton CW, Gallegly MR \& Litty VG (1966). Factors Affecting the Antigenicity of the Mycelium of Three Species of Phytophthora. Phytopathology 56: 422-426.

6. Dworschack RG \& Wickerham LJ (1961). Production of Extracellular and Total Invertase by Candida Utilis, Saccharomyces Cerevisiae, and other Yeasts. Appl
Microbiol 9: 291-294.

7. Souza MJ, Alves-Araújo C \& Pacheco A, Almeida MJ, Spencer-Martins I, Leão C (2007). Sugar Utilization Patterns and Respiro-Fermentative Metabolism in the Baker's Yeast. Torulaspora delbruecki Microbiol 75(153): 898-904.

8. Almeida ACS, Araujo LC, Costa AM, Abreu CAM, Lima MAGA \& Pahla MLAPFP (2005). Sucrose Hydrolysis Catalyzed by Auto-Immobilized Invertase into Intact Cells of Sladosporium Cladosporioides. E J Biotech 8(1):54-62.

9. Poonawalla FM, Patel KL \& Iyenger MRS (1965). Invertase Production by Penicillium Chrysenogenum and Other Fungi in Submerged Fermentation. Appl Microbiol 13(5): 749-754.

10. Bernfeld P (1955). Amylases $\alpha$ and $\beta$. Methods in Enzymology 1:49-58.

11. Guimarães LHS, Terenzi HF, Polizeli MLTM \& Jorge JA (2007). Production and Characterization of a Thermostable Extracellular B-D-Fructo suranosidase Produced by Aspergillus Ochraceus with Agroindustrial Residues as Carbon Source. Enzyme Microb Technol 42:52-57.

12. Sani A, Awe FA \& Akinyanju JA (1992). Amylase Synthesis in Aspergillus flavus and Aspergillus niger Grown on Cassava Peel. J Ind Microbiol 10:55-59.

13. Negi S \& Benerjee R (2006). Optimization of Amylase and Protease Production from Aspergillus Awamori in Single Bioreactor through EVOP Factorial Design Technique. Technol Biotechnol 44:257-261.

14. Sivaramakrishnan S, Gangadharan D, Nampoothiri KM, Soccol CR \& Pandey A (2006). Amylases from Microbial Sources An Overview on Recent Developments. Food Technol Biotechnol 44:173-184.

15. Mahdi BA, Bhattacharya A \& Gupta A (2012). Enhanced Lipase Production from Sp. S1 Using Sal Deoiled Seed Cake as Novel Natural Substrate for Potential In 
Dairy Wastewater Treatment. J Chem Technol Biotechnol 87: 418-426.

16. Egorov SN, Semenova IN \& Maksimov VN (2000). Mutual Effects of Invertase and Acid Phosphatase from the Yeast Saccharomyces Cerevisiae on Their Secretion into Culture Media. Mikrobiologiia 69: 34-37.

17. Hussain A, Khan ZI, Ahmad K, Ashraf M, Valeem EE \& Rashid MH (2010). Effect of an Enzyme Denaturant (Urea) On the Stability of Soluble Acid Invertases from Sugarcane. Pak J Bot 42(3): 2171-2175.

18. Herwig $C$, Doerries $C$, Marison I \& Stockar UV (2001). Quantitative Analysis of the Regulation Scheme of Invertase Expression in Saccharomyces Cerevisae. Biotechnol Bioengg 76:247-58.

19. Rubio MC, Runcoand R \& Navarro AR (2002). Invertase from A Strain of Rhodotorula Glutinis. Phytochem 61:605-9.

20. Ahmed K, Valeem EE, Haq Q, Mehmood I \& Dahot MU (2014). Optimal Conditions for the Production of Industrial Enzymes by Aspergillus Niger Using Agricultural Wastes as Sources of Carbon. FUUAST J Biol 4(2): 129-136.

21. Uroš A, Srdjan P \& Vujčić Z (2010). Purification and Characterisation of Saccharomyces Cerevisiae External
Invertase Isoforms. Food Chem 120(3):799804.

22. Ashokumar B, Kayalvizhi N \& Gunasekaran P (2001). Optimization of Media for B- Production by Aspergillus Nigerin Submerged and Solid State Fermentation. Process Biochem 37: 331338.

23. Quiroga EN, Vattunone MA \& Sampietro AR (1995). Purification and Characterization of Invertase from Pycnoporus Sanguineus. Biochem Biophys Acta 1251: 75-80.

24. Chaudhuri A \& Maheshwari R (1996). A novel invertse from a thermophilic fungus Thermomyces lanuginosus: its requirement of thiol and protein for activation. Arch Biochem Biophys 327(1):98-106.

25. Hocine L, Wang Z, Jiang B \& Xu S (2000). Purification and Partial Characterization of Fructosyltransferase and Invertase from Aspergillus Niger AS0023. J Biotechnol 81: 73-84.

26. Bhatti HN, Asgher M, Abbas A, Nawaz R \& Sheiki MA (2006). Studies on Kinetics and Thermo Stability of a Novel Acid Invertase from Fusarium solani. J Agric Food Chem 54: 4617-4623. 